\title{
Immigrants' Experiences on Integration While Attempting to Access the Labour Market: Implications for Social Work Practice
}

\author{
Reidun Ims ${ }^{1, *}$, Lennart Lorås ${ }^{2}$, Ottar Ness $^{3}{ }^{(1)}$ and Linda Finlay 4 \\ 1 Department of Social Studies, University of Stavanger, 4021 Stavanger, Norway \\ 2 Department of Welfare and Participation, Western University of Applied Sciences, 5020 Bergen, Norway; \\ lennart.loraas@hvl.no \\ 3 Department of Education and Lifelong Learning, Norwegian University of Science and Technology, \\ 7491 Trondheim, Norway; Ottar.ness@ntnu.no \\ 4 The Open University/Private Practice, York YO23 3 PS, UK; L.H.Finlay@open.ac.uk \\ * Correspondence: reidun.ims@uis.no
}

Citation: Ims, Reidun, Lennart Lorås, Ottar Ness, and Linda Finlay. 2021.

Immigrants' Experiences on

Integration While Attempting to

Access the Labour Market:

Implications for Social Work Practice.

Social Sciences 10: 121. https://

doi.org/10.3390/socsci10040121

Academic Editor: Caroline McGregor

Received: 13 January 2021

Accepted: 23 March 2021

Published: 29 March 2021

Publisher's Note: MDPI stays neutral with regard to jurisdictional claims in published maps and institutional affiliations.

Copyright: (C) 2021 by the authors. Licensee MDPI, Basel, Switzerland. This article is an open access article distributed under the terms and conditions of the Creative Commons Attribution (CC BY) license (https:/ / creativecommons.org/licenses/by/ $4.0 /)$.

\begin{abstract}
Background: The challenge of immigrants and their integration into adopted countries is a key topic for the global field of social work. However, there is a paucity of research on immigrants' lived experiences in gaining access to the labour market. Thus, this study examines how immigrants in Norway experience integration while in the process of gaining access to the labour market. The prevalent notion of integration achieved through gainful employment narrows the concept of integration and disguises the underlying marginalization and inequalities that are derived from majority- minority dividing lines. (2) Methods: Data were collected via nine qualitative semistructured interviews with ten immigrants (one interview was with a couple) living in Norway. Data was analysed by using Interpretative Phenomenological Analysis. (3) Results: The results showed that the participants experienced social exclusion but accepted this as an inevitable part of being an immigrant. The participants regarded the learning of Norwegian language as the key aspect to understanding social customs and forming informal relationships with native Norwegians and important for achieving integration. Freedom and equality were also regarded as issues of great importance. (4) Conclusions: The results provide the field of social work with important insights towards informing social work practices and challenging current paradigms.
\end{abstract}

Keywords: social work; qualitative research; interpretative phenomenological analysis; immigrants; integration; subjective experiences

\section{Introduction}

Immigrant integration is at the core of debates taking place in global institutions such as the United Nations [UN], the European Union [EU], the International Organization of Migration [IOM] and the Organisation for Economic Co-operation and Developments [OECD] (OECD/EU 2018; The European Commission 2016; United Nations 2017; International Organization for Migration 2018), and dominates destination countries' civic debates (Harder et al. 2018; Oliver and Gidley 2015). Immigrants are defined as individuals born abroad to two foreign-born parents and four foreign-born grandparents (Statistics Norway $2019 b$ ). Increased migration from less developed countries to the global North is fuelled by war, abuse, neglected human rights as well as climate change. This has prompted debates on how to include these new citizens successfully into general society and avoid their social exclusion (Harder et al. 2018; Oliver and Gidley 2015; Ott 2013). The growing numbers of immigrants and consistent disparities in employment rates support the need for more knowledge on integration through work for immigrants and how this knowledge can be used in the field of social work (Algan et al. 2010; Bratsberg et al. 2016; OECD/EU 2018; United Nations 2017). 
Social work has a crucial role in working with immigrants, focusing on individual needs and social justice as well as informing policy and practice. Integration and support for refugees and asylum seekers are established and growing fields in social work (Bø 2014; Boccagni 2015; Rine 2018; Valtonen 2001, 2015; Viola et al. 2018). Social workers on the frontlines of the welfare state are essential in implementing integration strategies and policies in practice (Terum et al. 2012; Rine 2018). Shifting policies, managerialism and marketization affect professional approaches and objectives (Weinberg and Banks 2019). This requires a strong focus on ethics, morals, and values from social work(ers) (Banks 2012). Social work includes a multitude of perspectives, and critical theories where anti-oppressive practice is central (Payne 2006). In anti-oppressive social work, the emphasis is directed towards transformation of power relations, aiming to reduce social inequalities (Danso 2009). Advocating for oppressed groups' rights and opportunities is central for social work practitioners (Danso 2009; Payne 2006). Ladhani and Sitter (2020) claim that anti-oppressive social work has reduced the importance of anti-racism in social work education as well as in practice. Payne (2006) suggests that anti-racism is part of anti-oppressive practice. Following this, in this article, anti-oppressive practice [AOP] comprises all forms of oppressive practices.

Integration through employment/work is a common goal in global integration-politics (Harder et al. 2018; OECD/EU 2018; Oliver and Gidley 2015). Harder et al. (2018) propose a definition of integration "... the degree to which immigrants have the knowledge and capacity to build a successful, fulfilling life in the host society" (p. 11484). We accede to this definition. In the present study, 'work' is defined as employment. Incorporation into the labour market is an indicator of both short- and long-term integration for refugees (Ott 2013). Though integration is considered a good thing in general, ambivalence is present within some immigrant-communities (Craig 2015). Norway, like the rest of the global North, has experienced growing population diversity (Statistics Norway 2019a) and so faces the challenge of social inclusion due to this. An exploration of immigrants' lived experiences of integration in Norway will provide knowledge applicable to other countries with similar attitudes to integration (including Sweden, the Netherlands, Germany, Italy, Canada, Switzerland).

The overarching objective in Norwegian integration-politics is to transform newly arrived immigrants into productive citizens and uphold the welfare state (Ministry of Justice and Public Security 2016a). In concurrence with Ott (2013), the OECD (2017) and the EU (OECD/EU 2018), self-provision by accessing the labour market is considered the best way to realize the ambition of integration (Ministry of Justice and Public Security 2016a). Integration facilitated by employment is assumed to guarantee a positive long-term integrational outcome (Ministry of Justice and Public Security 2016a). Hence, integration and work are entangled almost as a joint concept in the Norwegian discourse.

The Norwegian Introduction Programme for Newly Arrived Immigrants [NIP] is the most important measure for, and is paramount in, Norwegian integration policy (Djuve and Kavli 2019). NIP aims to provide asylum seekers, refugees, unaccompanied minors, and family reunified necessary qualifications to transfer into employment. The programme is mandatory for candidates aged $18-55$. The programme's aim is rapid and stable transfer into employment for immigrants (Ministry of Justice and Public Security 2016b). NIP offers language training and civic knowledge as well as job-training, and a relatively generous allowance. According to the OECD/EU (2018), employment rates are lower for immigrants than natives in all OECD and EU countries, and the gap has widened. Research specific to the Norwegian labour market shows similar conclusions (Bratsberg et al. 2016): Immigrants have lower employment rates than native Norwegians, at $67.1 \%$ for immigrants and at $78.5 \%$ for native Norwegians (Statistics Norway 2019c). Initial inclusion in the labour market prevents increased social security dependency (Bratsberg et al. 2016). Evidence from France, Germany and the UK supports the conclusion that immigrants struggle to transfer successfully into the labour market (Algan et al. 2010). In contrast, Bevelander and Irastorza (2014) found that immigrants in Sweden improved their employment rates, 
achieved income growth similar to natives, and transferred into middle-skilled positions. Reduced gaps between male and female immigrants, admission to governmental support programmes, the country or region of origin, education level and the employment sector affected the employment rates (Bevelander and Irastorza 2014). Employment rates during initial years in Sweden were low for low-educated refugees and those arriving through family reunification in comparison to labour migrants (Bevelander and Irastorza 2014).

Immigrants consider work important for integration (Sigad et al. 2018) yet they struggle to secure employment suitable for their training and skills (Danso 2009). Furthermore, immigrants from the global South are subjected to high risks of precarity in the global North due to increasingly deregulated labour markets in western economies (Lewis et al. 2014). Immigrants have more precarious jobs and face higher job insecurity which in turn affects their health in a negative way (Liu et al. 2019). Several studies claim that refugees are particularly vulnerable in the pursuit for work (Marbach et al. 2018; Llinares-Insa et al. 2020). Results from Germany show that labour barriers (bureaucratic distinctions between citizens and non-citizens, the structural system of legal regulations) impede immigrants participation in the workforce (Täubig 2019) and thus threaten integration. Evidence of ethnic penalties in Britain (Rafferty 2012), Norway (Fangen 2010), the Netherlands (Gracia et al. 2016) and Western countries in general (Midtbøen 2015) highlight barriers to immigrants' transition into the labour markets which in turn hinder integration. Suggestions of discriminatory, unjust, and oppressive practices call for anti-oppressive social work to counteract such practices and support immigrants in their integration efforts (Danso 2009).

Differing definitions and perceptions of integration complicate comparison across national borders, studies, and time (Harder et al. 2018; OECD/EU 2018; Oliver and Gidley 2015). In addition to differing definitions, scholars embrace contrasting perspectives and explanations. Grzymala-Kazlowska and Phillimore (2018) argue that an ethno-national focus in migration studies has continued to use the binary language of minority/majority, them/us and dominant/non-dominant. They suggest super-diversity as a more fruitful and satisfying lens for analysing issues in immigration (Grzymala-Kazlowska and Phillimore 2018). Levitas (2005) agrees that there is a need to challenge the binary language, and states that social exclusion is a problematic term as it proclaims the division between majorityminority categories as the primary division in society. Such an understanding disguises inequalities and differences between the included and presents a deceptive picture that is overly harmonious (Levitas 2005).

According to Skjervheim (2002), who draws on the phenomenological philosophy of Buber (1958), there are two fundamentally different approaches to dialogue, which promote symmetrical or asymmetrical relationships. We can perceive the Other as a subject (a Thou) or as an object (an It). The relationship we have with a thing/object (an It) is fundamentally different to the one we have with a person/subject (a Thou). This profoundly affects our perceptions and how the dialogue precedes.

An interaction between two subjects (I-Thou) finds common ground in focusing on an issue. The relationship between the two subjects is equal, and different from the issue which is the third part of this relationship. Meaning surfaces when both subjects direct attention/awareness towards the issue and explore this together. According to this theory we cannot fully understand the Others' subjective perspective. For that reason, the issue becomes the focal point in which we can explore, and gain understanding without disregarding individual standpoints.

When we perceive another person as an It-as something different from ourselvesallocating labels and definitions, we objectify the Other (Skjervheim 2002). This relationship has two parts, the subject and the issue which, in this case, includes both the topic for conversation and the Other. Disregarding the Other's perceptions, views, judgments, and experiences reduce the Other to an object, and the dialogue resembles a monologue. There is no common ground to explore because the subject perceives the Other as an object. Objectification forces the Other into the position of a spectator which prohibits the Others' 
opportunity to take part and be a participant in the dialogue. Differences in power and positions can lead to asymmetrical relationships.

Research across disciplines on integration and migration provide knowledge relevant to the practice of social work (Valtonen 2015). Nevertheless, research specifically aimed at social work is important to improve professional practice and education, as well as promote and voice the relevance of international social work concerning immigrants (Healy 2004; Viola et al. 2018). Shier et al. (2011) conducted a review of the international migration and social work literature, covering the period 1985-2008. A growing interest in the sociological aspects of why people move took over from social work research's initial focus on political context (Shier et al. 2011). A broad investigation revealed a strong focus on post-migration experiences. The studies focused on four major areas: (1) demographic or contextual aspects of migrants and migration, (2) service delivery, (3) physical and mental health, (4) macrostructural aspects related to migration (Shier et al. 2011). To inform social work in terms of practice, education, and professional values, the research should include more diversified perspectives (Shier et al. 2011).

Over the last few years, research regarding immigrants and integration within Norwegian welfare institutions and social work has intensified (Handulle and Vassenden 2020; Johansen and Studsrød 2019; Tembo et al. 2020). There is, however, a lack of empirical studies exploring the actual experiences of immigrants concerning work and integration. The immigrants' lived experiences regarding the association between integration and work is an important aspect, yet one that has been insufficiently explored. This study is concerned with immigrants who have a refugee background, including resettlement/quota refugees and those who have applied for asylum in Norway and gained residency whatever reason, as well as individuals who have residence through family reunification with someone in the aforementioned categories (Ministry of Justice and Public Security 2016a). The aim of this study is to contribute knowledge regarding how immigrants experience integration when they are attempting to secure work. The research question for this study is: How do immigrants experience integration while in the process of gaining access to the labour market?

\section{Materials and Methods}

The chosen methodology of Interpretative Phenomenological Analysis [IPA] is a research approach committed to examining how people make sense of their major life experiences and is therefore well suited for this study (Smith et al. 2009).

IPA has three major underpinnings, phenomenology, hermeneutics and ideography. Phenomenology seeks to describe lived experience and to connect directly and immediately with the world as we pre-reflectively experience it (Finlay 2011). Hermeneutic phenomenology (Heidegger and Schmidt 2010) places emphasis on 'being-in-the-world', interpretively exploring existential dimensions of embodied relationality. The idiographic focus ensures that each case is allocated attention and thorough analysis.

IPA aims for rich, interactive layers of interpretation, and renounces width for depth to ensure that the major topics, as opposed to those which appear most frequently, are identified. IPA recognizes that the most important experiences are often the most difficult to talk about. Insightful interpretation acknowledges this predicament with a careful analysis of the participants' experiences. Interpretations derive from the participants' accounts, fusing the participants' words and experiences with the interpretations carried out by the researcher.

The qualitative nature of the analysis required critical self-awareness on the researcher's part to ensure trustworthiness and dependability (Finlay 2002; Patton 2015). A phenomenological 'attitude' was adopted which attempted to bracket the author's prior assumptions in order to attend more fully to the participants' experiences. This reflexive attitude combined with recurring discussions among the authors was undertaken to ensure ethical conduct and methodological integrity. 


\subsection{Sample and Recruitment}

The purposeful selection consisted of six men and four women aged 18-55 (see Table 1). Further criteria were

- Refugees, asylum-seekers, or family members reunified with refugees or asylumseekers;

- Completed a year in NIP;

- Experiences of work and integration within the Norwegian welfare context.

The participants were recruited through the Norwegian Labour and Welfare Administration (NAV) and NIP. Employees of NAV and the Introduction programme enquired whether eligible candidates were interested in participating. The participants were informed that the study was unrelated to NAV and the Introduction programme, and that their participation in the study would not in any way affect their relationship with NAV or the Introduction programme.

Contact information for the participants who upheld their interest was forwarded to the first author to schedule interviews. The participants received thorough information about the study on several occasions. One possible participant retracted the initial consent, and one did not reply to numerous attempts to schedule an interview.

Table 1. Presentation of participants.

\begin{tabular}{|c|c|c|c|c|}
\hline Participants & Country of Origin & Time in Norway & Family Status & Employment Status \\
\hline Tarik & Syria & 1.5 & Unmarried & $\begin{array}{l}\text { Enrolled in } \\
\text { Introduction } \\
\text { programme }\end{array}$ \\
\hline Hamza & Syria & 2 & Married & $\begin{array}{c}\text { Enrolled in } \\
\text { Introduction } \\
\text { programme + Practice }\end{array}$ \\
\hline Nadia & Syria & 2 & Married & $\begin{array}{c}\text { Enrolled in } \\
\text { Introduction } \\
\text { programme + Practice }\end{array}$ \\
\hline Omar & Syria & 4 & Married, 3 children & Practice \\
\hline Anwar & Syria & 3 & Married, 2 children & $\begin{array}{c}\text { Enrolled in } \\
\text { Introduction } \\
\text { programme + Practice }\end{array}$ \\
\hline Mai & Burma & 10 & Married, 3 children & Practice \\
\hline Almaz & Eritrea & 6 & Married & Student + Job \\
\hline Eyob & Eritrea & 3 & Married, 1 child & $\begin{array}{c}\text { Enrolled in } \\
\text { Introduction } \\
\text { programme + Practice }\end{array}$ \\
\hline Iman & China & 5 & Unmarried, 1 child & $\begin{array}{c}\text { Enrolled in } \\
\text { Introduction } \\
\text { programme + Practice }\end{array}$ \\
\hline Nebez & Syria & 2 & Unmarried & $\begin{array}{c}\text { Enrolled in } \\
\text { Introduction } \\
\text { programme + Job }\end{array}$ \\
\hline
\end{tabular}

The participants had lived in Norway between $1 \frac{1}{2}$ and 10 years at the time of the interviews. Their language-skills varied, as did their amount of work-experience in Norway (0-2 years). They all lived in urban areas in the western part of Norway. Smith et al. (2009) suggest that the sample size should be limited to assure depth in the analysis. A limited number of participants will provide opportunity to make comparisons without losing idiographic meanings.

\subsection{Data Collection}

The empirical data were collected through nine qualitative interviews, with ten immigrants (one interview was with a couple) living in Norway. The interviews were conducted 
by the first author between September 2017 and May 2018. The interviews lasted between $50 \mathrm{~min}$ and $1 \mathrm{~h}$ and $45 \mathrm{~min}$. The interviews took place in a setting chosen by the participant (researcher's office, participant's homes, facilities of the Introduction programme). Three interviews were conducted in English, while six interviews were conducted in Norwegian. The participants were encouraged to speak freely about their experiences, generating spontaneous questions during conversations. All participants declined the offer to have an interpreter present. An audio-recorder was used during the interviews to ensure verbatim transcriptions.

Semi-structured interviews allowed the participants to share their experiences freely and elaborate on their lived experiences. The interview guide drew on questions about work experience and their current and future situation in order to explore the participants' experiences on work and integration. The raw data were analysed as shown in Figure 1 in the analysis section. A broad spectrum of utterances such as feelings and non-verbal communications were incorporated in the analysis (teary eyes, hand gestures, tone of voice). To better remember statements, phrases, noteworthy incidents and expressions of feelings, reflective entries were noted in a research diary. The notes were included in the interpretation of the participants' utterances.

\begin{tabular}{|c|c|c|c|}
\hline $\begin{array}{c}\text { Exploratory comments } \\
\text { (descriptive, linguistic, conceptual) }\end{array}$ & Original transcript & Emergent themes & Superordinate themes \\
\hline $\begin{array}{l}\text { Problem. } \\
\text { Islamic group or the government. }\end{array}$ & $\begin{array}{l}\text { Hamza: The problem is that half the Syrian people support } \\
\text { the Islamic group, and the other half support the } \\
\text { government. So, how can these people live together again? } \\
\text { Interviewer: Yeah, in peace? } \\
\text { Hamza: Many Syrians now live in Germany, in Norway. } \\
\text { They feel - me also - I feel the freedom. I never talk about } \\
\text { politics. Okay, I live in Norway, but it's not my country. For } \\
\text { example, I cannot talk about which political parties I like, } \\
\text { no. I can maybe just talk with my friend, but it's not my } \\
\text { country. I cannot vote, yeah. }\end{array}$ & $\begin{array}{l}\text { Entangled politics and religion } \\
\text { divide the country } \\
\text { Experiences of actual freedom }\end{array}$ & $\begin{array}{l}\text { Immigrants' experiences } \\
\text { on belonging, freedom } \\
\text { and equal chances } \\
\text { Immigrants' experiences } \\
\text { on belonging, freedom } \\
\text { and equal chances }\end{array}$ \\
\hline
\end{tabular}

Figure 1. Example of analysis.

\subsection{Research Ethics}

The data retention was approved by the Norwegian Centre for Research Data (NSD), (reference \# 55202). Careful, sensitive negotiation was required to protect participants from any consequences of participation and to reflect on uneven positions relating to language, gender, and context. To ensure voluntary and informed participation, the participants received thorough information about the study on several occasions. In addition, the participants received information on the possibility of withdrawing from the study (none did). Each participant signed the consent form. The participants were each allocated a pseudonym to ensure anonymity.

During the interviews, participants were at times overwhelmed by strong feelings such as sadness, anger, or despair as they referred to the trauma of their history and current experience. The interviewer (first author) was acutely aware of the sensitive nature of the data being collected and the importance of not overly traumatizing the participants. Drawing on her social work training, care was taken to respond respectfully and sensitively to participants' disclosures.

\subsection{Data Analysis: Interpretative Phenomenological Analysis}

The data were analysed through the systematic step-by-step approach suggested by Smith et al. (2009) aiming to pull out explicit and hidden meanings through iteratively examining the data (Finlay 2011). 
Step 1. Reading and re-reading the transcribed data ensured a deeper familiarity with the data, focusing on the participants' experiences on integration.

Step 2. Initial noting involved extensive annotation that resembled a free textual analysis. The research diary was revisited to incorporate the immediate remarks about feelings and non-verbal communications (teary eyes, hand gestures, tone of voice) in the analysis.

Step 3. Developing emergent themes meant organizing the large body of comments into clusters. This required focus both on details (looking for key-quotes/gems), and on the larger parts of the data (the overall theme(s) in the account). Comparing and contrasting emerging patterns and connections required a meticulous involvement with the transcript and the research diary to ensure inclusion of significant themes. When developing emerging themes, the original transcript merged with interpretations from the analyst.

Step 4. Searching for connections across emergent themes required focusing on the themes, aiming to discover interrelationships that was not uncovered in the previous step. Hidden or unnoticeable connections (appreciation as a possible drawback for integration) as well as the apparent ones (the importance of language) were noted. The different themes were listed and moved about on the computer, and a hard copy was printed out. This enabled stepping back to get an overview of all the themes. Clusters of themes connected, emerging as a persisting focus revealed connections. New lists were allocated to gather and re-evaluate the emergent themes. This process was repeated until the themes appeared explicit and covered the account's major results in a meaningful way.

Step 5. Moving to the next case meant repeating the process. The procedure covering the analytical steps was carried out for each interview, aiming to start afresh while at the same time acknowledging the undeniable preconceptions emerging.

Step 6. Looking for patterns across cases is the final step. To get an overview of the data, paper copies were laid out on the floor and marked with different colours for each participant. Gazing at the themes-alternating between the different accountsunveiled interrelationships and connections as well as contradictions. Themes were cut out and moved around to ensure a thorough process, mirroring the alterations between part and whole. The process was repeated several times to ensure reliable chains of connections. The results from the analysis are the three following themes: (1) Freedom as heaven: Superficial belonging, traumas, and lack of empathy, (2) Language as the key: Lack of arenas to learn language and social customs, and (3) Inevitable discrimination: Immigrants' lived experiences of categorization and discrimination.

\section{Results}

Three themes emerged from the analysis process: (1) Freedom as heaven: Superficial belonging, traumas, and lack of empathy, (2) Language as the key: Lack of arenas to learn language and social customs, and (3) Inevitable discrimination: Immigrants' lived experiences of categorization and discrimination. These themes accentuate a variety of topics related to integration, including freedom, belonging, lacking empathy, language, social relationships, implicit rules, categorization and discrimination.

\subsection{Freedom as Heaven: Superficial Belonging, Traumas, and Lack of Empathy}

A strong sense of belonging, entangled with the worst experiences of their lives, complicated the participants' relationships with their motherland. The participants regarded being safe and receiving fair and respectful treatment fundamental in their decision to stay in Norway.

The participants experienced violations, torture, maltreatment, and threats from the authorities in their country of origin and suffered physically and emotionally because of it. Freedom as they found it in Norway was non-existent in their motherlands. The participants still missed customs and traditions from their motherland as well as friends and family. Returning to their motherland would mean giving up the freedom and equality that 
they greatly appreciated and could leave them subjected to retaliation. Anwar explained why he would never return to live in Syria: "Norway is freedom! I came to heaven, and what I left behind was hell."

The civic rules that included every individual and were followed by everyone, appeared surprising yet imperative for the participants' perception of society. To them, this demonstrated equality and a just allocation of advantages which they did not recognize from before. Corruption, nepotism, and the unequal distribution of opportunities in their homelands derailed their chances to realize ambitions such as education. The participants seemed to value the lack of censorship as well as equally distributed opportunities in education and social mobility in their adopted country. Being able to rely on personal skills and abilities rather than status, money and power-relations appeared to open new possibilities for them.

The participants were surprised to learn that the authorities designed schemes to ease their transition into the labour market as well as provide them with financial support. They emphasized the governmental support system as paramount in their experience of feeling integrated and part of society. While experiencing this welcoming and greatly facilitated integration scheme, the participants described feeling confused and diminished when native Norwegians perceived them as a group of hungry, poor, and helpless refugees. Almaz described how uncomfortable she was with the label refugee:

I felt inferior to people. ( . . ) I did not feel part of Norwegian society, but like a kind of bug that Norwegians had to take care of. I hated the word refugee. Then I realized, of course I'm a refugee to this country, but everyone is a refugee, I said to myself. ( . . . ) Refugee is just a word, it doesn't describe me, or my situation.

The participants experienced that people they met in practice placements asked questions that they perceived as disrespectful (Are your family starving? Do wild animals roam the streets outside your home?). The participants seemed hesitant to challenge such perceptions. Mai said: "I felt like crying in front of them, and I wanted to tell them to stop. You don't understand what we have lived through. I wanted to say that, but I didn't dare." To the participants this appeared as a deficiency in understanding and empathy for their circumstances. They felt devalued and minimized.

\subsection{Language as the Key: Lack of Arenas to Learn Language and Social Customs}

Speaking the language and understanding social customs was considered essential to achieving social inclusion. The participants found it difficult to make lasting relationships with Norwegians, and felt they had to justify their frequent gatherings with friends from their own country.

Several of the participants characterized language as the main key to integration. Language represented understanding, but also the ability to engage and interact with native Norwegians as well as other immigrants. Iman explained: "If I go to a room, I need to open the door, to do that I need a key. For me, language is that key". The Norwegian language was described as a difficult language to learn, because of the limited practice opportunities afforded outside classroom walls and a lack of contact with native Norwegians. Despite recognizing language as the key to achieving integration, the participants considered the training provided by the government to be insufficient to prepare them for work and for a social life.

The participants were reliant on administrative programmes to form relationships with Norwegians and described the support system as crucial for participation and integration.

They struggled to understand how to establish stable relationships with Norwegians. Omar described; "If you greet a new neighbour, you approach him with a 'hi' and a 'good afternoon'. Sometimes he sees you but doesn't greet you back. That is strange. How can one build a social network from that?" The participants expressed that Norwegians, unlike themselves, seemed to need an appointment and a purpose to engage in social interaction. To the participants, their traditions of a close social life appeared to cause distrust amongst 
native Norwegians. The participants felt as if they had to defend their right to socialize, justifying that social gatherings did not prevent them from working. Almaz said:

When I'm at home, I want to invite many people to my home, to share a meal. And they [Norwegians] see us gathering and say, 'Ah, refugees never work. They just stay at home and eat'. That seems to be the impression the Norwegians have of us.

The participants also noted that the learning and understanding of implicit and unwritten rules was demanding. They regarded interaction with natives as essential to understanding social customs and how to conduct themselves. Hamza explained: "We have to understand where we are living. And we have to understand that the rules are different here, and so is the social life." The participants who formed relationships with native Norwegians (families hired by the municipalities to provide support) considered the experience helpful. Almaz said; "I have a Norwegian family now, which helps me to be integrated (...)" She explained that they helped her to understand the language, implicit and unwritten rules as well as behaviour that seemed strange (like going outside in the pouring rain).

\subsection{Inevitable Discrimination: Immigrants' Lived Experiences of Categorization and Discrimination}

Several of the participants experienced unpleasant situations in Norway. In their own words, they consciously refused to acknowledge the significance and impact of such events. Nevertheless, the possibility of such occurrences evoked self-consciousness about their performance and conduct.

Offensive and disrespectful behaviour seemed to occur regularly. Iman experienced people passing by the unoccupied seat next to her on a full bus, Tarik experienced that a neighbour claimed that all Muslims were dangerous, while Omar met a woman scared to accept a helping hand from him - a bearded man with Arabic facial features. These experiences suggested bias or intolerance. The participants seemed to wrap abusive events in a tone of harmony, downplaying their significance. Most of the participants seemed reluctant to describe events that caused them sorrow or made them feel uncomfortable. It was as if they felt they were disloyal or ungrateful if they voiced concern and raised awareness about the possibility of prejudice/discrimination.

However, overhearing remarks from someone who disliked their presence because of their status as an immigrant or their appearance inflicted emotional pain. Tarik said:

I have sat on the bus listening to people, Norwegians, saying that they don't like, or can't stand to see immigrants here in their motherland. Most people would, however, say that you are welcome, you must live your life and be safe.

Though they felt uncomfortable, angry, or provoked, the participants underlined that unpleasant encounters were rare, and most people were pleasant and welcoming. The participants justified transgressions against themselves as minor incidents of little importance. They consciously directed their focus to occurrences they perceived as uplifting and filled with joy to help them minimize negative encounters. Nevertheless, some events seemed to rattle the participants. Tarik described an encounter with a Norwegian man:

He asked why we came to his motherland. He said 'You must go back. We don't like Muslims here'. I didn't understand what he said, but my friend understood everything, and he answered. ( . . . ) 'I can't live there, why do you say these things? We are humans!' He [the Norwegian man] said 'No, I don't like Muslims'.

Prejudice caused some stress but mostly fatigue for the participants. They experienced embodied reactions of sadness. These reactions prompted a need to protect themselves. Iman said: "I have to let it go, because I don't want to have more stress, I will be sick. So, I say, it's okay, it's okay." The participants seemed to spend a fair amount of energy making sense of what happened to them and attempting to reduce the impact it had on their lives. It appeared as if they accepted discrimination as an inevitable part of being an immigrant. 
The participants tended to withhold their reactions, believing anger and sadness would weigh them down. The participants' previous experiences seemed to strengthen their inclination to focus on the positives and handle difficult events with awareness, respect, and concern. Nebez explained: "I cut an old man's hair. He said, 'Your Norwegian is really good.' When someone supports you like that you want to keep going." Positive encounters seemed to have a stronger bearing on how the participants felt and how they made sense of interactions with hostile individuals.

\section{Discussion}

The aim of this study is to gain insight into how immigrants experience integration while in the process of gaining access to the labour market. The focus on the immigrants' own voices and subjectively lived experiences ensures a contemporary relevance concerned with diversity and inclusiveness/integration. This study contributes to the growing literature that recognises the experiences of immigrants and challenges they face, during the process of getting work (Sigad et al. 2018; Täubig 2019). The discussion summarizes key results and considers implications for social work practice and professional values.

\subsection{Contribution of the Study}

The results suggest that the participants embraced and accepted the close association between integration and work, as they regularly stated that work was important for their integration. Their difficulties in securing a job caused them to experience a sense of social exclusion. Consequently, their psychological fulfilment, as well as their ability to take part in society and realize their ambitions was limited by their lacking inclusion and participation. Further, our results show that the participants' search for work became a struggle for integration. This is in line with the studies of Algan et al. (2010), Bevelander and Irastorza (2014) and Bratsberg et al. (2016), who all found that immigrants struggle to transfer successfully into the labour market. Our results show that the emphasis on integration through work seemed to intensify the struggle to gain employment. This is also found in Sigad et al.'s (2018) study that concluded that work was considered important for integration by immigrants. The findings in Täubig's (2019) study suggested that participation in the workforce was impeded by barriers. For the participants in our study, having a job was key to realizing other aspects concerned with integration such as housing, health and social links, which also appeared important to them. The close association between work and integration heightened the importance of work as a prerequisite for integration in the participants' minds. In their minds, the inability to secure a job implied a failing, and ultimately impeded integration. Several scholars challenge the narrow measurement of successful integration as limited to gainful employment (Craig 2015; Halvorsen 2012; Kildal 2012; Oliver and Gidley 2015). Nevertheless, the close association between integration and work gives work a prominent role in integration. The immigrants' acceptance of the prevailing idea of integration through work suggests that they have become spectators. We would argue that lacking acknowledgment of their views and experiences have forced the immigrants into a spectator position.

The participants in our study appreciated the freedom and equal chances they perceived as embedded in Norwegian society. However, they lacked the experience and knowledge to benefit fully from the opportunities. The results suggests that the participants' integration was restricted and impeded by their lack of Norwegian cultural knowledge which, in turn, hindered their capabilities to participate in integration activities. Especially, because they described that they lacked knowledge on Norwegian social customs, language, implicit and unwritten rules. Dialogue should facilitate and promote understanding of immigrants' existing knowledge so that measures can support their individual needs and efforts. Our results show that the participants experienced integration differently. Lack of individualised interventions, and disregard for individual resources and characteristics, could thus pose a threat to integration. Immigrants must strive towards integration, utilizing individual resources and characteristics. Still, governmental schemes 
must prevent the responsibility for integration to be totally individualized. In our view, adjusting integration schemes to individual needs would benefit both individuals and society. According to Harder et al. (2018), capability and knowledge are equally important dimensions in integration. Suggestions of a discrepancy between short-term and long-term results have been raised by scholars (Bratsberg et al. 2016). This knowledge of immigrants' difficulties in transferring to and maintaining a place in the workforce should lead social work professions to give more support for immigrant rights and their equal and just treatment (Danso 2009) Furthermore, insist that social work's unique contribution is recognized and capitalized on.

Our results revealed that participants appeared to link unpleasant encounters and transgressions with past experiences. They grew accustomed to and accepted intolerance as an inevitable part of being an immigrant. Intolerance violates the ethical principles embedded in social work. Social work's focus on non-discriminatory practices suggests a need to critically re-evaluate immigrants' position in general society drawing on the participant-spectator distinction suggested by Skjervheim (2002). The participants' acceptance of violations raised the concern whether integration-to the participants-relied on their ability to accept transgressions and present themselves as deserving immigrants (Børhaug 1999; Danso 2009; Valtonen 2001; Weinberg and Banks 2019). Ethics as a starting point for deliberations on integration could raise the focus on moral responsibility (Børhaug 1999). Furthermore, it would nuance the debate and create an opportunity for the incorporation and acknowledgement of immigrants' voices. Moreover, this would make room for a more substantial influence from social work practice and knowledge (Danso 2009; Valtonen 2001; Viola et al. 2018; Weinberg and Banks 2019). It appeared that the participants' inclusion was dependent on their ability to condone discriminatory practices. Børhaug (1999) and Weinberg and Banks (2019) suggested a need to focus on the ethics and moral responsibility embedded in the practice of social work and called for a focus on anti-oppressive practices to promote structural change, and advocate for equality (Danso 2009). Such practices should start by acknowledging the importance of equality through dialogue and should perceive immigrants as equal partners.

The results suggested that the participants experienced social exclusion and felt it prevented them from becoming full members of society. Levitas (2005) problematized the term social exclusion stating that it discloses problematic issues associated with inequalities and marginalization rather than illuminating them. Discourses on integration traditionally formed on the axis of binary language, as stated by Grzymala-Kazlowska and Phillimore (2018), maintaining the traditional dividing-lines and ways inequalities are perceived. Levitas (2005) stated that thinking along minority-majority lines covered up differences. However, being part of majority or minority did not necessarily uncover structural disadvantages imperative to social inclusion (Levitas 2005). Diversity and super-diversity acknowledge the complexity and multifaceted nature of immigration (Boccagni 2015; Grzymala-Kazlowska and Phillimore 2018; Vertovec 2007). According to Boccagni (2015), social work is a well-suited field for evaluating the conceptual transition from diversity towards superdiversity. Although social work is excellently equipped to meet such requirements, the challenge lies in transferring honorary wording into practice (Boccagni 2015). A dialogue focused on honouring social work's ethical principles such as human dignity, right to autonomy and solidarity requires an acknowledgment of immigrants as equal partners.

The participants perceived establishing lasting relationships with native Norwegians as a superior opportunity that would enable integration. However, the participants found it difficult to establish such relationships. By the same token, insufficient opportunities to socialize with native Norwegians made implicit social customs hard to understand and language practice fragmented. Enhanced language skills would, as they perceived it, facilitate participation in general society. The participants who experienced close relationships with Norwegian families regarded it as important and helpful in their integration. When understood as a two-way process, integration suggested reciprocal interactions, including 
people already living in Norway as well as those who moved there (Ministry of Children, Equality and Social Inclusion 2013). However, governmental expectations, with no steps taken to ensure effort from immigrants and natives, simply remained expectations. The reciprocity relied on individuals, organizations, or municipalities. Positive experiences supported the participants' yearning for informal contact. We suggest that there is potential to include native Norwegians in the integration of immigrants, which could stimulate integration for immigrants as well as securing knowledge and familiarity, widening the concept of integration. Integration of immigrants is an important topic for social work practice (Bø 2014; Boccagni 2015; Rine 2018; Valtonen 2001, 2015; Viola et al. 2018). Social works professional commitment to social change suggest that social work should pilot and govern such initiatives, fusing governmental and private engagement to improve immigrants' integration in Norway.

\subsection{Implications for Social Work Practice}

Social work is a practice-oriented profession dedicated to preventing social problems, solving or reducing the impact of social problems, or improving life opportunities (Eide and Skorstad 2013). Based on the results we argue that it is necessary to adopt more effective measures in social work aiming to support immigrants' own efforts for integration. To counteract individualized responsibility for integration, social work must continue to address and challenge structural issues and social inequalities, as suggested by AOP (Danso 2009; Dominelli 2017; Thompson 2016). Furthermore, it is substantial to adopt a broader view for what integration entails. Integration through work is the preferred trajectory in Norway. The knowledge on immigrants' difficulties in maintaining stable employment should widen the concept, realizing that integration can be achieved through a stronger emphasiz on language, relationships with Norwegians and measures designed to promote social change and redistribution of welfare to even out living conditions.

AOP is advocated by scholars such as Dominelli (2017), Thompson (2016), Danso (2009) and more. According to de Montigny (2011) the focus on AOP in social work education and practice narrows social workers' ability to discover the complex causes of human suffering. When social workers generally consider oppression the reason for difficulties, misery or anguish, the risk for overlooking other sources for suffering is imminent (de Montigny 2011). de Montigny (2011) suggests that focus on oppression, power and privilege forms a seal that prevent social workers from discovering and challenging causes other than oppression, power and privilege. We would argue that AOP's focus on social inequalities and structural injustice paired with interpretation of subjective lived experiences is an example of a discovering attitude. Thus, our results indicate that a discovering attitude, focused on exploring, is achievable within a framework of AOP.

Social work's professional values suggest a stronger focus on the experience's immigrants have gained. Recognition of these unique experiences represents an opportunity to adapt and develop more suitable integration schemes. As participants suggest, informal contact can play a decisive role in learning language, as well as the unwritten and implicit rules of society. Informal contact is a chance to support immigrants' independence and promote integration. It could support their opportunities to form new relationships and their ability to exploit the opportunities in Norwegian society. Furthermore, this would start to fuse different communities together through interplay.

Social work is first and foremost about social change and should focus on immigrants' need for support to achieve integration. The results of this study show a need for custommade support that builds on individual needs and resources as well as addresses the barriers to integration. Following Buber (1958), our findings suggest that a collaborative approach which respects the personhood, capability and autonomy of the immigrant, rather than a controlling one based on power differential, is called for. To counteract the pernicious aspects of social control, social work needs to uphold ethical principles and promote non-discriminatory practices, advocating solidarity with immigrants. 
This study has shown that learning the host language was crucial for the participants to be integrated. Language involves language proficiency but also the ability to understand general society. The participants described the skills they gained in the introduction programme as insufficient in terms of developing language proficiency. They expressed a desire to enhance their skills by practising and thereby refining their abilities. We would argue that social work should promote and facilitate such opportunities by advocating additional language-training.

Social work's person-in-environment approach suggests that immigrants' experiences can generate important knowledge for practice, values, and education. Social work recognizes the importance of experiences. It is thus important to acknowledge everyone as an independent voice in the multivoiced reality (Bakhtin 1984), while facilitating dialogue as suggested by Skjervheim (2002).

\subsection{Limitations}

Qualitative analysis draws heavily on the researcher's ability to be critically aware of built-in assumptions as well as differences in language and culture. We believe sensitivity to context and impact/importance has been demonstrated by engaging with this topical issue related to diversity and inclusion. Transparency and rigour have been demonstrated by providing evidence in the analysis with extensive quotations. Overall, we believe that the study adopted a suitably rich idiographic approach, and the 'double hermeneutic' process enabled a reflective focus on the participants' subjective lived experience. That said, the results remain emergent, partial, and tentative.

A purposefully sampled group of people with lived experiences of integration and work shared their experiences. This study aims to provide some understanding of integration experienced by immigrants in the process of gaining work. As this study draws on the participants' subjective accounts, it is challenging to replicate. Nevertheless, it would be an important task to carry out similar research to verify and nuance the results.

The interviews were carried out and transcribed by the first author. As the participants' accounts were the focus of attention, they chose which language the interviews were conducted in. The limitations of language proficiency were, in part, counteracted by attending carefully to non-verbal language such as body-language, gestures and tone of voice. Equally important, the analysis ensured that the participants' embodied emotional responses were included in the interpretations.

Each participant was offered an interpreter but chose to reject this opportunity. The opportunity to speak in one's native language would probably ensure more precise and raw expression of thoughts/feelings. However, the presence of an interpreter might have restricted the participants' free speech and would have involved another layer of interpretation where unintended meanings creep in.

Given the lack of information available concerning immigrants' experiences related to work and integration, this study — despite its limitations_addresses the gap and provides important knowledge for professional practice and to inform policy creation. Perhaps its most important contribution is the inclusion of the immigrants' own voices. Such an honouring of their expressed experience is desperately needed in any ongoing debate on integration.

This study has a relatively small sample, and-in line with its qualitative epistemologyis not generalizable. A small study can, however, be transferable and relevant outside its locality. Evidence from Norway can provide insights relevant to similar contexts in other countries. Furthermore, this would suggest a solid base for designing research in other contexts and for designing quantitative research to assess the range and generalisability of the findings. Further research should go deeper into individuals' different experiences. A profound and more committed phenomenological approach using fewer participants or research with a larger sample applying methods such as grounded theory, mixed methods and survey methods could begin the process of recognising different types of immigrant experiences, contexts and needs. Attention needs to be paid to different organizational 
and occupational settings, as well as health issues in future research regarding immigrants, work and integration.

Author Contributions: The first author, R.I. had the primary responsibility for writing the drafts, conducting the analysis and submitting the manuscript. Together with the second author and the third author, the first author discussed and revised the data analysis. The second author L.L. and the third author O.N. contributed to all the drafts. The fourth author L.F. contributed to the manuscript at a later stage. All authors have read and agreed to the published version of the manuscript.

Funding: This research received no external funding.

Institutional Review Board Statement: The study was conducted according to the guidelines of the Declaration of Helsinki and approved by the Norwegian Centre for Research Data (reference number \# 55202).

Informed Consent Statement: Informed consent was obtained from all subjects involved in the study.

Data Availability Statement: The data presented in this study are available on request from the corresponding author. The data are not publicly available due to their sensitivity.

Conflicts of Interest: The authors declare no conflict of interest.

\section{References}

Algan, Yann, Christian Dustmann, Albrecht Glitz, and Alan Manning. 2010. The Economic Situation of First and Second-Generation Immigrants in France, Germany and the United Kingdom. The Economic Journal 120: F4-F30. [CrossRef]

Bakhtin, Mikhail. 1984. Problems of Dostoevsky's Poetics. Minneapolis: University of Minnesota Press.

Banks, Sarah. 2012. Ethics and Values in Social Work, 4th ed. New York: Palgrave Macmillan.

Bevelander, Pieter, and Nahikari Irastorza. 2014. Catching Up: The Labor Market Integration of New Immigrants in Sweden. Washington, DC: Migration Policy Institute and International Labour Office.

Bø, Bente Puntervold. 2014. Social work in a multicultural society: New challenges and needs for competence. International Social Work 562-74. [CrossRef]

Boccagni, Paolo. 2015. (Super)diversity and the migration-social work nexus: A new lens on the field of access and inclusion? Ethnic and Racial Studies 38: 608-20. [CrossRef]

Børhaug, Frédérique. 1999. Hvilke etiske prinsipper bør integrering av innvandrere bygge på?: En teoretisk drøfting med utgangspunkt i Emmanuel Lévinas' tenkning. Utbildning E Demokrati 8: 8-11.

Bratsberg, Bernt, Oddbjørn Raaum, and Knut Røed. 2016. Flyktninger på det norske arbeidsmarkedet. Søkelys på arbeidslivet 32: 185-207. [CrossRef]

Buber, Martin. 1958. I and Thou. New York: Charles Scribner's Sons.

Craig, Gary. 2015. Migration and Integration: A Local and Experiential Perspective. Iris Working Paper Series: 7/2014. Birmingham: Institute for Research into Superdiversity.

Danso, Ransford. 2009. Emancipating and Empowering De-Valued Skilled Immigrants: What Hope Does Anti-Oppressive Social Work Practice Offer? The British Journal of Social Work 39: 539-55. [CrossRef]

de Montigny, Gerald. 2011. Beyond Anti-Oppressive Practice: Investigating Reflexive Social Relations. Journal of Progressive Human Services 22: 8-30. [CrossRef]

Djuve, Anne Britt, and Hanne Cecilie Kavli. 2019. Refugee integration policy the Norwegian way-Why good ideas fail and bad ideas prevail. Tansfer: European Review of Labour and Research 25: 25-42. [CrossRef]

Dominelli, Lena. 2017. Anti-Racist Social Work, 4th ed. London: Red Globe Press.

Eide, Solveig Botnen, and Berit Skorstad. 2013. Etikk—Til Refleksjon og Handling i Sosialt Arbeid. Oslo: Gyldendal Akademisk.

Fangen, Katrine. 2010. Social exclusion and inclusion of young immigrants: Presentation of an analytical framework. Young 18: 133-56. [CrossRef]

Finlay, Linda. 2002. “Outing" the Researcher: The Provenance, Process, and Practice of Reflexivity. Qualitative Health Research 12: 531-45. [CrossRef]

Finlay, Linda. 2011. Phenomenology for Therapists: Researching the Lived World. Chichester: Wiley-Blackwell.

Gracia, Pablo, Lucía Vázquez-Quesada, and Herman G. Van de Werfhorst. 2016. Ethnic penalties? The role of human capital and social origins in labour market outcomes of second-generation Moroccans and Turks in the Netherlands. Journal of Ethnic and Migration Studies 42: 69-87. [CrossRef]

Grzymala-Kazlowska, Aleksandra, and Jenny Phillimore. 2018. Introduction: Rethinking integration. New perspectives on adaptation and settlement in the era of super-diversity. Journal of Ethnic and Migration Studies 44: 179-96. [CrossRef]

Halvorsen, Nut. 2012. Lønnsarbeidet-Vår tids sekulære religion. In Arbeidslinja. Arbeidsmotivasjonen og Velferdsstaten. Edited by Stjernø Steinar and Øverbye Einar. Oslo: Universitetsforlaget, pp. 188-98. 
Handulle, Ayan, and Anders Vassenden. 2020. 'The art of kindergarten drop off': How young Norwegian-Somali parents perform ethnicity to avoid reports to Child Welfare Services. European Journal of Social Work 1-12. [CrossRef]

Harder, Niklas, Lucila Figueroa, Rachel M. Gillum, Dominik Hangartner, David D. Laitin, and Jens Hainmueller. 2018. Multidimensional measure of immigrant integration. Proceedings of the National Academy of Sciences of the United States of America. [CrossRef]

Healy, Lynne M. 2004. Strengthening the Link. Journal of Immigrant E Refugee Services 2: 49-67. [CrossRef]

Heidegger, Martin, and Dennis J. Schmidt. 2010. Being and Time: A Revised Edition of the Stambaugh Translation. New York: State University of New York Press.

International Organization for Migration. 2018. World Migration Report 2018. Geneva: International Organization for Migration.

Johansen, Kristina, and Ingunn Studsrød. 2019. "Help goes around in a circle": Young unaccompanied refugees' engagement in interpersonal relationships and its significance for resilience. International Journal of Migration, Health and Social Care 15: 249-61. [CrossRef]

Kildal, Nanna. 2012. Fra arbeidsetos til insentiver og velferdskontrakter. In Arbeidslinja. Arbeidsmotivasjonen Og Velferdsstaten. Edited by Stjernø Steinar and Øverbye Einar. Oslo: Universitetsforlaget, pp. 177-87.

Ladhani, Sheliza, and Kathleen C. Sitter. 2020. The Revival of Anti-Racism. Critical Social Work 21: 55-65. [CrossRef]

Levitas, Ruth. 2005. The Inclusive Society?: Social Exclusion and New Labour, 2nd ed. Basingstoke: Palgrave Macmillan.

Lewis, Hannah, Peter Dwyer, Stuart Hodkinson, and Louise Waite. 2014. Hyper-precarious lives: Migrants, work and forced labour in the Global North. Progress in Human Geography 580-600. [CrossRef]

Liu, Xiaomin, Steven J. Bowe, Allison Milner, Lin Li, Lay San Too, and Anthony D. LaMontagne. 2019. Job Insecurity: A Comparative Analysis between Migrant and Native Workers in Australia. International Journal of Environmental Research and Public Health 16: 4159. [CrossRef]

Llinares-Insa, Lucía I., Manuel Roldán-Pardo, Pilar González-Navarro, and María Desamparados Benedito-Monleón. 2020. Well-Being without Employment? Promoting the Employability of Refugees. International Journal of Environmental Research and Public Health 17: 7775. [CrossRef]

Marbach, Moritz, Jens Hainmueller, and Dominik Hangartner. 2018. The long-term impact of employment bans on the economic integration of refugees. Sciences Advances 4. [CrossRef]

Midtbøen, Arnfinn H. 2015. Ethnic Penalties in Western Labour Markets: Contributions, Explanations, Critiques. Nordic Journal of Migration Research 5: 185-93. [CrossRef]

Ministry of Children, Equality and Social Inclusion. 2013. En Helhetlig Integreringspolitikk: Mangfold og Fellesskap (Meld. St. 6 (2012-2013)); Oslo: Departementet.

Ministry of Justice and Public Security. 2016a. From Reception Centre to the Labour Market-An Effective Integration Policy (Meld. St. 30 (2015-2016)); Oslo: Departementet.

Ministry of Justice and Public Security. 2016b. Rundskriv til lov om Introduksjonsordning og Norskopplæring for Nyankomne Innvandrere (Introduksjonsloven) (Rundskriv G-01/2016). Available online: https://www.regjeringen.no/contentassets/4b44b3 ea29554b4aa1e9169829b75b78/g-01-2016.pdf (accessed on 30 October 2020).

OECD. 2017. Making Integration Work: Family Migrants. Paris: OECD Publishing.

OECD/EU. 2018. Settling in 2018: Indicators of Immigrant Integration. Paris: OECD Publishing/Brussels. [CrossRef]

Oliver, Caroline, and Ben Gidley. 2015. Integration of Migrants in Europe. Available online: https://www.compas.ox.ac.uk/wpcontent/uploads/OSIFE15-Report.pdf (accessed on 2 November 2020).

Ott, Eleanor. 2013. The Labour Market Integration of Resettled Refugees. Geneva: United Nations High Commissioner for Refugees.

Patton, Michael Quinn. 2015. Qualitative Research \& Evaluation Methods: Integrating Theory and Practice, 4th ed. Thousand Oaks: SAGE Publications, Inc.

Payne, Malcolm. 2006. Teorier i Socialt Arbejde. København: Hans Reitzels forlag.

Rafferty, Anthony. 2012. Ethnic penalties in graduate level over-education, unemployment and wages: Evidence from Britain. Work, Employment and Society 987-1066. [CrossRef]

Rine, Christine M. 2018. The Role of Social Workers in Immigrant and Refugee Welfare. Health \& Social Work 43: 209-12. [CrossRef]

Shier, Micheal L., Sandra Engstrom, and John R. Graham. 2011. International Migration and Social Work: A Review of the Literature. Journal of Immigrant $\mathcal{E}$ Refugee Studies 9: 38-56. [CrossRef]

Sigad, Laura I., Zvi Eisikovits, Roni Strier, and Eli Buchbinder. 2018. The meaning of work among immigrants living in poverty in Israel: Replanting roots of belonging. International Journal of Social Welfare 27: 197-206. [CrossRef]

Skjervheim, Hans, ed. 2002. Deltakar og tilskodar. In Mennesket. Oslo: Universitetsforlaget, pp. 20-35.

Smith, Jonathan A., Flowers Paul, and Larkin Michael. 2009. Interpretative Phenomenological Analysis. Theory, Method and Research. London: Sage Publications Ltd.

Statistics Norway. 2019a. Innvandrere og Norskfødte Med Innvandrerforeldre. Available online: https://www.ssb.no/befolkning/ statistikker/innvbef/aar/2019-03-05 (accessed on 28 February 2020).

Statistics Norway. 2019b. Slik Definerer SSB Innvandrere. Available online: https://www.ssb.no/befolkning/artikler-ogpublikasjoner/slik-definerer-ssb-innvandrere (accessed on 21 December 2020).

Statistics Norway. 2019c. Sysselsetting Blant Innvandrere. Available online: https://www.ssb.no/arbeid-og-lonn/statistikker/ innvregsys/aar/2019-03-05 (accessed on 21 February 2020). 
Täubig, Vicki. 2019. Work as real life in the context of organised disintegration-A perspective on the everyday life of refugees. Identities 26: 339-55. [CrossRef]

Tembo, Memory Jayne, Ingunn Studsrød, and Susan Young. 2020. Governing the family: Immigrant parents' perceptions of the controlling power of the Norwegian welfare system. European Journal of Social Work, 1-12. [CrossRef]

Terum, Lars Inge, Tufte Per Arne, and Jessen Jorunn Theresia. 2012. Arbeidslinja og sosialarbeiderne. In Arbeidslinja: Arbeidsmotivasjonen og Velferdsstaten. Edited by Stjernø Steinar and Øverbye Einar. Oslo: Universitetsforlaget, pp. 79-95.

The European Commission. 2016. Action Plan on the Integration of Third Country Nationals. Available online: https:/ / ec.europa.eu/homeaffairs / sites/homeaffairs / files / what-we-do/policies / european-agenda-migration/proposal-implementation-package/docs / 20160607/communication_action_plan_integration_third-country_nationals_en.pdf (accessed on 30 October 2020).

Thompson, Neil. 2016. Anti-Discriminatory Practice: Equality, Diversity and Social Justice, 6th ed. London: Red Globe Press.

United Nations. 2017. Making Migration Work for All; Report of the Secretary-General. Available online: https: / refugeesmigrants.un.org/ sites/default/files/sg_report_en.pdf (accessed on 29 October 2020).

Valtonen, Kathleen. 2001. Immigrant integration in the welfare state: Social work's growing arena. European Journal of Social Work 4: 247-62. [CrossRef]

Valtonen, Ms Kathleen. 2015. Social Work and Integration in Immigrant Communities: Framing the Field. Surrey: Ashgate.

Vertovec, Steven. 2007. Super-diversity and its implications. Ethnic and Racial Studies 30: 1024-54. [CrossRef]

Viola, Erica, Elena Biondo, and Cristina O. Mosso. 2018. The Role of Social Worker in Promoting Immigrants' Integration. Social Work in Public Health 33: 483-96. [CrossRef] [PubMed]

Weinberg, Merlinda, and Sarah Banks. 2019. Practising Ethically in Unethical Times: Everyday Resistance in Social Work. Ethics and Social Welfare 13: 361-76. [CrossRef] 